of The Arrival, and the second with the visual and verbal peritext, colour, panels, frames, perspective, symbolism and the complex combination of reality and fantasy.

The third part of the book starts with chapter 8 , in which the authors discuss the types of mediation used to interpret The Arrival. Some questions the mediators asked the children are described, together with the interaction the children achieved during the literary sessions.

The final chapter claims that the findings of the study could be used for the better inclusion of immigrant children into school systems. Image-based narratives, often overlooked in school curricula, contribute to the intellectual advancement of all pupils, so teachers should include as much imagery in their teaching as possible. The authors offer some strategies for literary understanding of image-based narratives. The chapter ends with a commentary by some teachers who participated in the inquiry.

The book's coda, A (Visual) Journey to Italy, describes the findings that researchers from the University of Bologna reported after replicating the study in Italy. After the study was conducted, the participating immigrant children highlighted the amount of new Italian words they had learned through group discussions, which also helped improve their selfesteem. This shows that reading wordless picturebooks helps immigrant students overcome the language barrier and boosts their confidence.

This book is a valuable and interesting read for every teacher, scholar and student in the field of children's literature, as well as scholars from other fields such as psychology, pedagogy and education. Well-organised and understandable to a wide audience, the book offers insights into the way children convey meaning from such intricate wordless narratives. As Shaun Tan himself says in the foreword, children tend to look carefully at concrete details in pictures, whereas adults are often overly preoccupied with understanding meaning (xiv). Imaginative ideas and emphatic responses combined with a deep understanding of the characters' feelings show the vast potential of a child's imagination when steered in the right direction.

Ana Stilinović

\title{
The Hidden World of Tove Jansson
}

Tuula Karjalainen. 2016. Tove Jansson: Work and Love. Trans. David McDuff. London: Penguin Random House. 304 pp. ISBN: 9781846148484

DOI: $10.21066 /$ carcl.libri.2016-05(02).0014

Tove Jansson: Work and Love will surprise! As the life of this cherished and renowned picturebook creator unfolds, it is clear that the children's books for which she is so famous were only a small part of her work. Tove Jansson did in fact only produce three picturebooks, which she created alongside her Moomin stories and numerous lesser known artistic works, including cartoon strips, stamps, theatre productions, films, adult novels and her greatest love - paintings. David McDuff's translation of Tuula Karjalainen's book was brought out by Penguin in the UK in 2016 to coincide with two major London exhibitions about this famous writer/illustrator: one at the Southbank Centre and the other at the Dulwich Picture Gallery. Both of these focus quite heavily on Jansson's artistic talents as, according to Karjalainen, Tove Jansson dreamed of becoming an artist of renown although she later had to come to terms with the fact that her fame was eventually due to her children's books. 
I was first introduced to Tove Jansson's work in 1996, during the developmental stages of the European Picture Book Collection (www.ncrcl.ac.uk/epbc), when my Finnish colleague chose Who Will Comfort Toffle? (Vem ska tröst knyttet?) as Finland's contribution to the Collection. I was stunned by the artwork and endless atmospheric images that this artist created with just the flick of a brush stroke, producing textures that could make her characters appear filled in and strong, or wispy-thin and insignificant. By making her protagonists look directly at her readers, Jansson has the ability to focus on "the outsider" (a feeling she had herself) and portray emotions such as fear, loneliness, solitude and love with a minute precision. Her excess use of colour and exuberance, too, contrasts happy moments with the sadder times of her black and white scratchy characters. When, at the story's dénouement, Toffle actually finds somebody even more scared and unloved than himself, Karjalainen suggests that this perhaps sums up Tove Jansson's feelings through much of her life, and she has in fact entitled one of her chapters "What Do You Do With a Seashell If There Is No One to Show It To?" - a direct quote from this picturebook.

Jansson herself describes Who Will Comfort Toffle as "a picture book for children about being in love and accepting love", as the plot consists of "longing for someone and the desire to find a partner" (201). This is how Karjalainen presents the artist's life in Tove Jansson: Work and Love. She manages to encapsulate the essence of Jansson's being and gives us the opportunity to discover more about not only her picturebooks, but also her personal life and other achievements. Karjalainen's book mainly focuses on how Jansson was influenced by her Finnish islands, how she was affected by the wars in Finland, their aftermath and her retreat to Sweden which was unaffected by war. She also discusses Jansson's loves, both heterosexual and homosexual, and British influence on the publication of her works for children, because the translations became popular before she was accepted in Finland. The chapters are divided into themes which focus on different elements of Jansson's work and love. Whilst this is extremely illuminating, it does necessitate a certain flexibility of reading as the time frame jumps around quite a lot, causing much repetition of events and reversal in time, which is somewhat confusing. The illustrations and early photos, however, make up for this and are liberally spread throughout this beautiful book from beginning to end.

Chapter One concerns itself with Jansson's father's art and her mother's pictures. Both being artists obviously laid the foundations for Tove's own creativity and Karjalainen provides many family anecdotes which illuminate these relationships, including revelations such as that although "Tove's relationship with her father was burdened by many conflicts and sometimes coloured by plain hatred, the bond between them never broke" (3), or that life with mother was like living "under a bell jar" (10). Focus is also placed on the close relationship she had with her brothers and the important role they played in her life, especially Per Olaf who took pictures for the Moomin book An Unwanted Guest. Chapter Two moves on to relate Tove's experiences of youth and war and her grief when her friend Eva moved to America. Their letters form a large part of this chapter, as her friend is sorely missed, but Tove finds solace in her pictures of horror and colours in a wicked world. During this period, a stormy love affair developed between Tove Jansson and Tapio Tapiovaara, which opened her eyes to politics and dreams of living in Morocco.

Chapter Three highlights Jansson's work and love and the beginnings of her Moomin stories, but it is Chapters Four, Five and Six which bring to life the real Moomins, Jansson's 
road towards fame and how the Moomins conquered the world, with the previously mentioned seventh chapter, "What Do You Do With a Seashell If There Is No One to Show It To?", focusing on picturebooks. These four chapters, which are likely to prove the most insightful to lovers of her children's books, follow the development of the Moomin characters from a sketch in a letter to one of her friends, paintings in 1947 and fairy-tale frescos, to the birth of the Moomins, Moominvalley, the Finn Family Moomintrol (1948), and the first Moomin play. Her journey towards success helps us to discover how the Moomins managed to achieve international popularity. Chapter Eight takes us back to Jansson's real love, that of painting. Even though she was a hard-working artist, however, her exhibitions often had "a lukewarm reception" (211). By this time, she had also spent seven years of intensive work on comic strips for children, but felt that cartoons were "life threatening to all forms of narrative" (221), so moved towards writing books for children and about children - the theme of Chapter Nine. Unfortunately, these did not have the same success as her Moomin stories and, when Tove's mother died, she devoted herself to three books of mourning.

By the time Tove reached the age of sixty-four, she decided to visit Paris, hoping that she would be able to find "freedom and colour", the title of Chapter Ten. The sorrowful self portrait on the facing page as this chapter begins, tells the rest. She said, "If I don't get my teeth into my painting now I will never try to paint again: this is the last chance. I don't even know if it's all that important, and I can't be bothered to think about it" (239). Fortunately, she found contentment in "life and living" and Chapter Eleven explores this, focusing on the successful radio dramas, theatre and television series that she produced. It also emphasises that her islands, where she spent so much time with the love of her life, Tuulikki Pietila, were "the best things" she had ever had (249). As Jansson takes her leave in Karjalainen's final chapter, we are presented with the two women, Tove and Tuulikki, as they enjoy being together at the end of their lives, with Tove reflecting that "she had lived an exciting and colourful life, though it had also been a strenuous one" and "the two most important things in it had been work and love" (277).

Above all, what comes through when reading Tove Jansson: Work and Love is how much of Tove Jansson there is in all her stories. Every character she has created appears to have been influenced by either a member of her family or close friends, and she has shared these relationships with her readers. Right up until the end of her life, she was writing for adults, but it was her Moomin stories that captured the world and will always be her bestknown work. Tuula Karjalainen's book is a testimony to this work and love, and opens up a hidden world to all those who have loved Tove Jansson's stories. In spite of some repetition, all children's literature enthusiasts will enjoy the detailed references to Jansson's life experiences and how they have influenced the visual creativity which exudes from her work for children. It is almost as if we are being treated to share an Aladdin's cave of moments in Tove Jansson's life which have helped her to grow into an internationally wellloved household name for so many children and their parents. 